\title{
Energy resources on the Internet
}

\author{
By Carl D. Phillips
}

\section{There are lodes of energy sites to check out}

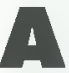

s a field of study, energy is multidisciplinary, involving most of the basic sciences, engineering, resource studies, environment, development, and public policy. As a result, getting a good grasp of the literature can be daunting. The problem can be even more complex when tracking down energy information resources on the Internet since a good storage and retrieval system does not exist for finding Internet-based resources at this point. This paper can begin to put you in touch with the vast amount of quality information available.

Included are directories, government agencies, labs and institutes, and data resources, as well as specific energy sector-related materials. Most of the material available is in the form of research abstracts, technical reports, raw and processes data sets, and general educational overviews.

\section{Major guides to energy resources}

These are two of the few sources that are available for broad coverage of the energy field. They are less than adequate but useful as starting points.

- Energy Information on Internet. A fairly comprehensive group of more than 200 resources, updated monthly. Each entry has a record attached to help you determine the usefulness of the resource. Access: http://www.ecn. $\mathrm{nl} / \mathrm{eii} / \mathrm{main} \cdot \mathrm{html}$.

- WwW Virtual Library Energy Resources Guide. Mostly geared towards alternative energy resources. This guide is arranged in alphabetical order. Access: http://solstice. crest.org/online/virtual-library/VLib-energy. html.

\section{Directories}

Locating commercial, industrial, and researchoriented entities is possible by using one of these continually growing directories.

- Energy Yellow Pages. A nicely organized listing of mostly commercial contacts such as trade associations, suppliers, engineers, equipment vendors, and services. Includes research organizations and publications. Listings are not all Internet accessible; however, when they are, a direct link is provided. Access: http: $/ /$ www.ccnet.com/ nep/yellow.htm.

- Directory of Energy-Related Graduate Programs in U.S. Universities. Categorizes interdisciplinary energy programs by institution, type, and state. Records for each program describe the degrees offered, general focus, size of faculty, special facilities, number of students, etc. Access: http://solstice.crest.org/renewables/ $\mathrm{grac} /$ index.html.

- The Source for Renewable Energy. Directory of more than 1,300 renewable energyrelated businesses. Businesses are organized by geographic location, business type, and product type. Records list business type, product type, address, phone number, e-mail, and URL when appropriate. Access: http://www.rmii. $\mathrm{com} /$ theSource/renewableEnergy/.

\section{Government agencies}

Governments can be a particularly good place for finding quality information related to energy. Most U.S. government materials are copyright free so their distribution via the Internet becomes more likely. 
There's more than

\section{ONE}

way to do most things. You can have

\section{ONE}

serials management company, and

\section{ONE}

document delivery service, and

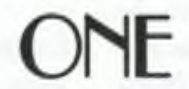

source for CD-ROM databases and yet another

\section{ONE}

for full text, index and abstract database searching.

But why would you want more than

\section{ONE}

when there's

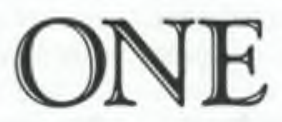

integrated source that can do it all for you?

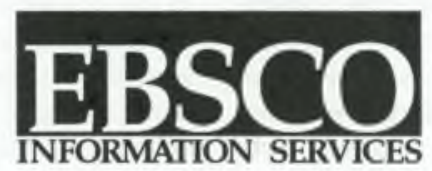

Phone: (205) 991-6600 • Fax: (205) 995-1636

Web site: http://www.ebsco.com 
- California Energy Commission. This widely known and very active agency provides a wealth of energy information. Included are educational overviews, technical reports, data, government initiatives/programs, and even education programs for kids. Access: http:// www.energy.ca.gov/energy/homepage.html.

- Canada's Department of Natural Resources Energy Sector. Provides connections to a variety of the agency's energy-related materials. Access: http://es1.es.emr.ca/.

- United States Department of Energy. A vast site of energy information. Connections to many of the department's field offices, laboratories, and programs, which in themselves are replete with valuable energy-related materials. Of particular value is OPENNET, a database that references the department's declassified information. Several of these documents are also available in full text. Another important resource is the Electronic Exchange Initiative which provides electronic exchange of scientific and technical documents. A must-see site. Access: http://apollo.osti.gov/home.html.

- United States Environmental Protection Agency. Provides full-text access to a large number of agency publications. Includes facts, data, educational documents, the EPA Joumal, and reference sources such as the latest environmental Federal Register listings and a dictionary of environmental acronyms and terminology. Access: http://www.epa.gov/.

\section{Labs and institutes}

Many labs and research institutes are available via the Internet. Here are a few selected sites for finding mostly scientific, technical, and program reports.

- Princeton University's Center for Energy \& Environmental Studies. Offers bibliographies of its technical reports from 1990 through 1994, theses from 1975 through 1994 , and a selected list of faculty and staff publications. Access: http://www.princeton.edu:80/ $\sim$ cees/.

- Risoe National Laboratory. Dedicated to research in three main areas: 1 ) energy technology and energy planning; 2) environmental aspects of energy and industrial and plant production; and 3) materials and measuring techniques for industry. Citations to recent research and other publications are provided; ordering is free. Access: http://www.risoe.dk/risoe.html.

- Texas A\&M's Energy Systems Laboratory. Focusing primarily on alternate energy, energy conservation, and HVAC (heating, ventilation, and air conditioning), this Web site provides access to the lab's research publications and energy software programs. Access: http:// www-esl.tamu.edu/.

- University of California Energy Institute. Its research covers the general areas of resources and supply technologies, energy use efficiency, and the impact of energy use on health, the environment, and the economy. Research publication abstracts and, in some cases, the full text can be viewed. Order forms provided for many items. Access: http://wwwucenergy.eecs.berkeley.edu/UCENERGY/.

- U.S. Department of Energy Laboratories. A comprehensive list of hyperlinks to the 30 National Labs. Access: http://apollo.osti.gov/ $\mathrm{html} /$ servers/labtitls.html.

\section{Data sources}

Real world data is accessible from many locations on the Net. The trouble is that it has not been sufficiently collected in one place to provide a sense of what is available. These sites are major collectors and distributors of raw and processed data.

- Electric Utility Statistical Database. Data include Tables of Operating Statistics, Proposed Natural Gas Price Forecast, DJ-COB Electricity Price Index, U.S. Electricity Production, etc. Regular installments of data to be provided. Access: http://www.energyonline.com/Restructuring/energydb/estathme.html.

- Energy Data Page. An extremely valuable resource for locating data on the Net. The attempt is to bring together in one place useful data from selected international, governmental, and industrial sites. Much is already available. Access: http://gaia1.ies.wisc.edu/research/ energydata/hankpage.html.

- Gator Power Academic Interface. Dedicated to the distribution of real world data to the academic/research community, raw and processed data are collected from selected $\mathrm{CO}$ generation control system sensors and made available here. The site expects to continue facilitating archiving and processing data, developing graphic interfaces to operating data, illustrating the use of scientific/data visualization tools, and developing and valiclating algorithms for data analysis. Access: http://gatorpwr.che. ufl.edu/.

- Solar Radiation Data. Solar and climatic data primarily intended for the siting, specification, and sizing of solar energy equipment. 
Data can be accessed via clickable image maps or menus. Organized by selected U.S. locations and a variety of directional angles of flat-plate collectors. Access: http://solstice.crest.org/ renewables/solrad/index.html.

- US DOE Energy Information Administration. This is the U.S. government's statistical agency with primary responsibility for the collection and dissemination of energy data and data analysis. There are lots of raw data, as well as analysis and forecasting publications. A tremendously useful site. Access: http:// www.eia.doe.gov.

- WORID ENERGY Data Base for the International Energy Annual 1993. An informational site about how to access the International Energy Annual in its paper published form or its online database via ftp. Some digested data are included in the "Overview" of recent trends in world energy production and consumption. Access: http://www.eia.doe.gov/ emeu/world/main1.html.

\section{Energy sector-related sites}

Information related to specific energy sectors is widely available on the Internet. Below are sites that either represent possibilities or serve as pointers to resources within a particular sector.

\section{Alternative Fuel Vebicles}

- Centre for Alternative Transportation

Fuel. Actively engaged in alternative fuels development, the centre's staff maintains a database of technical papers. A quarterly called the CATF Review will shortly be available via this server. Access: http://www.bcr.bc.ca/catf/ default.htm

- Yahoo's Alternative Fuel Vehicles Index. Electric and solar vehicle sites and organizations. Access: http://www yahoo.com/Recreation/Automobiles/Alternative_Fuel_Vehicles/.

\section{Electric utilities}

- Electric Power Research Institute (EPRI). A source of extensive and broad research endeavors. The site is of particular value for its EPRI databases of products (more than 1,300 ), publications (more than 11,000 ), projects (more than 29,000), and technical experts (more than 200). Abstracts and ordering information provided. Access: http://www.epri.com/.

- The www Virtual Library for Power Engineering. A nicely organized collection of Internet resources for the public utility indus- try. Access: http://www.ece.iit.edu/ power/ power.html.

\section{Fossil fuels}

- Fossil Energy (FE) World Wide Web Network. The Office of Fossil Energy's connections to program reports, scientific and technical reports, global project reports, FE news, and more. Access: http://www.fe.doe.gov/.

- IEA International Centre for Gas Technology Information (ICGTI). The technology centre of the International Energy Agency (IEA), ICGTI is a forum for technology transfer and communication within the gas industry. Free registration required for access to all information resources which include: Question \& Answer Board, Industry Events, Technology Library, Experts Networks, etc. Access: http://www.gasinfo.dk/gasinfo/.

- Petroleum Internet Resources. A wellorganized, nearly comprehensive listing. Access: http://www.ghgcorp.com/geoprobe/petrol html

\section{Geotbermal energy}

- International Geothermal Association. Educational overviews, data, news articles, workshops, and conference proceedings available via this page. Access: http://www demon. co.uk/geosci/igahome.html.

\section{Nuclear energy}

- Nuke Home Page. An array of pointers to research institutes, publications, and nuclear plants. Access: http://nuke.Westlab.com/.

- United States Nuclear Regulatory Commission. Contains primarily information about the commission. Some standard technical specification documents and general educational materials about reactors are available in full text. Other documents are mentioned along with ordering information. Access: http: //www.nrc.gov/.

\section{Renewable energy}

- Energy Efficiency and Renewable Energy Network (EREN). This is the DOE's site responsible for qualitative information about renewable energy and energy-efficient technologies. Includes the latest announcements, press releases, funding information, conference calendars, newsletters, and magazines. See the clearinghouse for fact sheets and other educational materials. Access: http://www.eren. doe.gov/. 
- National Renewable Energy Laboratory. The U.S. National Lab primarily responsible for renewable energy and energy efficiency research. Lots of fact sheets and reports. Access: http://nrelinfo.nrel.gov/.

- Renewable Energy and Sustainable Energy Systems in Canada. Canadian government studies. Abstracts and ordering information provided for books, magazines, and papers. Access: http://spinne.web.net:80/ sustenergy/welcome.html.

- Solstice: Internet Information Service for the Center for Renewable Energy and Sustainable Technology. Extremely valuable resource for general information about all types of renewable energy technologies. Access: http: //solstice.crest.org/.

\section{Software}

- The Energy Science and Technology Software Center (ESTSC). Governmentproduced, energy-related software to run on personal computers, mainframes, and supercomputers. Searchable database with many features for locating the software you need. Software is available on diskettes or magnetic tape along with supporting documentation. Access: http://www.doe.gov/html/osti/estsc/estsc.html.

\section{Other interesting sites}

- Critical Mass Energy Project. An energy activist homepage. Find activist alerts, voting records, informational publications, etc., regarding public energy policy in the areas of nuclear power and reactor safety, radioactive waste policy, cutting polluter pork from the energy budget and tax code, renewable energy, energy efficiency, and transportation and fuel economy. Access: http://www.essential.org/ $\mathrm{CMEP} /$.

- UnCover. The table of contents of approximately 17,000 interdisciplinary periodicals. Key-word search capability is helpful for finding energy- related articles. Document delivery is available. Access: http://www.carl.org/uncover/unchome.html.

- Energy Newspage. A subscription-based service to news stories from many of the world's leading energy periodicals. Access: http:// www.newspage.com/NEWSPAGE/cgi-bin/ walk.cgi/NEWSPAGE/info/d13/.

\section{Newsgroups}

There are not many newsgroups dealing with energy issues; this is a fairly comprehensive list.
- alt.energy.renewable. Fueling ourselves without depleting everything. Access: news:alt.energy renewable.

- alt.solar.photovoltaic. Generating voltage from the sun's energy. Access: news:alt. solar.photovoltaic.

- clari.biz.industry.energy. Oil, gas, coal, alternatives (moderated). Access: news: clari.biz.industry.energy.

- misc.industry.utilities.electric. Discussions about the electric utility industry. Access: news:misc.industry.utilities.electric.

- sci.energy. Discussions about energy, science, and technology. Access: news:sci.energy.

- sci.energy.hydrogen. All about hydrogen as an alternative fuel. Access: news:sci. energy hydrogen.

\section{Discussion lists}

This is the majority of groups using mailing list software for discussing energy topics.

- AE. Alternative Energy Discussion List. Subscribe: listserv@sjsuvm1.sjsu.edu.

- ANURT-L. Advanced Nuclear Reactor Technology. This was formed to facilitate substantive discourse regarding the worldwide advocacy, design, and deployment of advanced nuclear reactor technology. Subscribe: listserv@ vml.hqadmin.doe.gov.

- Bioenergy Mailing List. A mailing list for the discussion of biomass as a sustainable energy resource. It intends to involve industry, academia, and government in discussions about future directions of research and industry. Subscribe: bioenergy-request@solstice.crest.org.

- ENCON-L. Energy Conservation Management Issues in Higher Education. Subscribe: listserv@listserv.syr.edu.

- Energy-L. Energy Issues in Israel. Subscribe: listserv@taunivm.tau.ac.il.

- EV. Electric Vehicle Discussion List. Subscribe: listserv@sjsuvm1.sjsu.edu.

- Hydrogen. Hydrogen as an alternative fuel. Subscribe: listserv@uriacc.uri.edu.

- IASEE-L. Discussion List on Solar Energy Education. Subscribe: LISTSERV@VM.GMD.DE.

- Novel-fuels. Research into fuel cells and new energy techniques. Subscribe: listserver@ic. ac.uk.

- NRCCE-L. List for the National Research Center for Coal and Energy. Subscribe: listserv@ wvnvm.wvnet.edu.

- Solar_utilities. Distributed Solar Energy Utility Business Development. Subscribe: majordomo@world.std.com. 


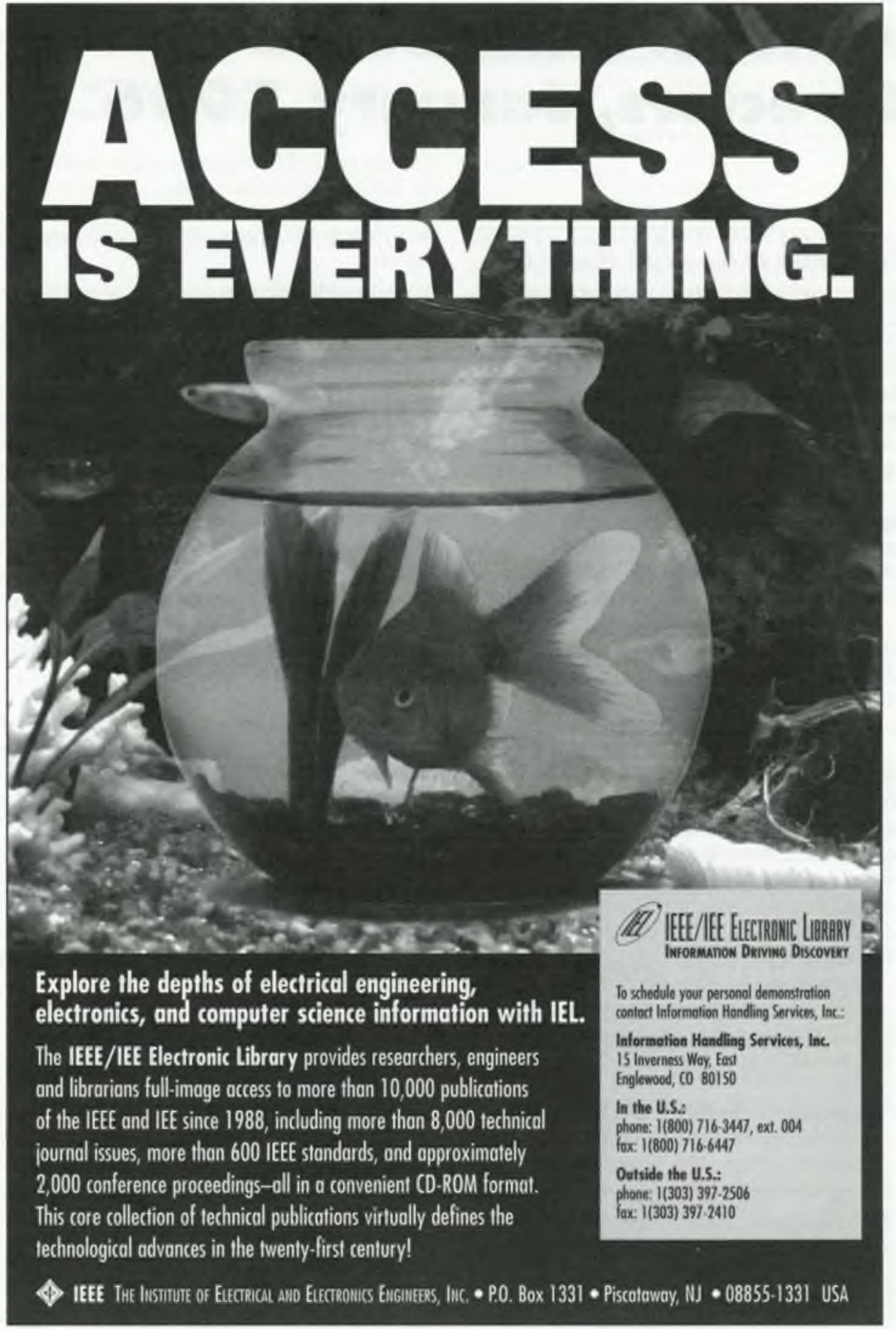

